\title{
Underestimating the Gender Gap? An Exploratory Two-Step Cluster Analysis of STEM Labor Segmentation and Its Impact on Women
}

\author{
Blanca Minerva Torres-Olave \\ Loyola University Chicago, btorresolave@luc.edu
}

Follow this and additional works at: https://ecommons.luc.edu/education_facpubs

Part of the Education Commons

Author Manuscript

This is a pre-publication author manuscript of the final, published article.

\section{Recommended Citation}

Torres-Olave, Blanca Minerva. Underestimating the Gender Gap? An Exploratory Two-Step Cluster Analysis of STEM Labor Segmentation and Its Impact on Women. Journal of Women and Minorities in Science and Engineering, 25, 1: 53-74, 2019. Retrieved from Loyola eCommons, Education: School of Education Faculty Publications and Other Works, http://dx.doi.org/10.1615/

JWomenMinorScienEng.2019021133

This Article is brought to you for free and open access by the Faculty Publications and Other Works by Department at Loyola eCommons. It has been accepted for inclusion in Education: School of Education Faculty Publications and Other Works by an authorized administrator of Loyola eCommons. For more information, please contact ecommons@luc.edu.

\section{(c) $(\mathrm{B})($}

This work is licensed under a Creative Commons Attribution-Noncommercial-No Derivative Works 3.0 License. (c) Begell House, 2019. 
Running Head: UNDERESTIMATING THE GENDER GAP?

Underestimating the Gender Gap? An Exploratory Two-Step Cluster Analysis of STEM Labor Segmentation and Its Impact on Women

\author{
Blanca M. Torres-Olave \\ Loyola University Chicago
}

This is an Accepted Manuscript of an article published by Begell House in the Journal of Women and Minorities in Science and Engineering, Vol. 25(1), available online DOI: 10.1615/JWomenMinorScienEng.2019021133

Author Note

Blanca M. Torres-Olave, Higher Education, Loyola University Chicago

The author thanks Edna Parra for technical assistance. This research was supported by a fellowship from the Mexican National Council for Science and Technology (Consejo Nacional para la Ciencia y Tecnología - CONACYT) as well as the Mexican Ministry of Education (Secretaría de Educación - SEP).

Correspondence concerning this article should be addressed to Blanca Torres-Olave, Loyola University Chicago, School of Education, 820 N Michigan Ave. Rm. 1130, Chicago, IL 60611. E-mail: btorresolave@ luc.edu 
Running Head: UNDERESTIMATING THE GENDER GAP?

\begin{abstract}
Gender inequality in science and technology fields takes various and complex shapes, from recruitment and retention across educational levels, to job entry and advancement barriers, and to pay and compensation. Although the salary gap for women in these fields is well-documented, much of the relevant research has relied exclusively on mean earned wages to estimate compensation differentials by gender. This approach may underestimate the actual extent of the gender gap than if more comprehensive measures of compensation (e.g. wages along with health insurance and retirement benefits) were used. Through a two-step cluster analysis of the 2008-2010 U.S. Census Survey of Income and Program Participation (SIPP), in this study I considered wages along with access to employer-provided health and pension benefits, as well as job characteristics like union membership, part-time employment, and access to employer-provided training, to explore labor segmentation in the science and technology workforce. The findings reveal a pattern consistent with labor segmentation, including the presence of clusters with secondary employment characteristics (i.e. low wages, part-time employment, and lack of health insurance and pension benefits). Significantly, women were overrepresented in such clusters, as well as in part-time and contingent work arrangements more generally. The findings both support and complicate the evidence from prior research on the gender gap by illustrating the cumulative impact that measures of total compensation can have in assessing the true extent of compensation disparities between men and women, and by highlighting the stratification of highly-skilled labor in the new economy.
\end{abstract}

Keywords: wage inequality, women, science, labor segmentation 
Running Head: UNDERESTIMATING THE GENDER GAP?

\section{Introduction}

The representation and status of women in Science, Technology, Engineering, and Math (STEM) fields is one of the most pressing challenges facing education and workforce policy in the United States. Despite concerted efforts in recent decades to foster more equitable opportunities for girls and women to pursue STEM education from the $\mathrm{K}-12$ level through college, women continue to enroll in STEM majors at lower rates than men, particularly in the fields of engineering and computer science (Kanny, Sax, \& Riggers-Piehl, 2014). The gender imbalance persists into the workforce: Even though women constituted $50 \%$ of the college-educated workforce in 2013 , they accounted for only $39 \%$ of employed individuals whose highest degree was in a STEM field, and 29\% of all workers in STEM occupations (National Science Board [NSB], 2016).

Beyond sheer numeric representation, the status of women in these fields also remains unequal. Over half a century since the passing of the Equal Pay Act of 1964, women scientists and engineers continue to earn less than men in both academic and nonacademic settings. That women earn considerably less than men-even after controlling for a wide set of characteristics such as education, age, work experience, years since completing the highest postsecondary degree, employment sector, field of degree, and geographical region - is one of the most robust facts in the STEM employment research (Langdon, McKittrick, Beede, Khan, \& Doms, 2011; National Science Board [NSB], 2012; National Science Foundation [NSF], 2016; Grey-Bowen \& McFarlane, 2010). According to the National Science Board (2012), salary differences between men and women remained largely unchanged in the 15-year period between 1993 and 2008. After controlling for the factors mentioned above, women's wages are estimated to be between $13-16 \%$ less than 
Running Head: UNDERESTIMATING THE GENDER GAP?

men's amongst bachelor's degree holders and 8-9\% less than men's amongst master's and doctoral degree holders.

The salary gap in STEM occupations is thus well-documented by empirical evidence. However, it is important to note that much of the relevant research uses earned wages as the main or only variable to examine the compensation gap. Yet there is substantial evidence from analysis of the general population that this approach may underestimate the actual extent of compensation differences (Kristal, Cohen, \& Mundlak, 2011; Pierce, 2001; Piketty \& Saez, 2003), especially in terms of the gender gap (Ghilarducci \& Lee, 2005). More comprehensive measures of compensation (e.g. wages along with access to employerprovided health insurance and/or retirement benefits) are necessary to better capture the breadth and depth of the gender gap.

In this article, I present findings from an exploratory cluster analysis of the 20082010 U.S. Census Survey of Income and Program Participation (SIPP), in which I considered wages along with broader measures of total compensation, including access to employer-provided benefits (health insurance and retirement), as well as job characteristics associated with job security like union membership, full- or part-time employment, and access to employer-provided training, to establish the impact that these variables have on employment and compensation patterns among STEM workers in the SIPP 2008 database. The study draws on Labor Market Segmentation (LMS) theory and on the literature on labor relations in the new economy. LMS theory asserts that the U.S. labor market is divided in two distinct segments based on employment characteristics: A “primary" market characterized by jobs with high wages, access to employment benefits and career ladders, and stable and secure employment; and a "secondary" market associated with low wages, 
Running Head: UNDERESTIMATING THE GENDER GAP?

few or no employment benefits, part-time or contingent contracts, and few possibilities for advancement or the acquisition of skills.

The study examined data on individuals employed in STEM occupations to determine the degree to which the STEM workforce exhibits characteristics associated with a segmented labor market. The two-step cluster analysis revealed the presence of distinct segments characterized not only by earning differentials, but also by qualitative differences in working conditions including but not limited to total compensation (e.g. wages and benefits), job stability, and access to training. At the same time, the findings suggest that labor restructuring has complicated the nature of contingent labor, resulting in a heterogeneous employment landscape for STEM and other highly-skilled workers — one with significant implications in terms of establishing the true size of the gender gap.

In the following section I discuss the history and main tenets of LMS theory, as well as relevance and limitations in the study of labor relations in the new economy. Next, I present an overview of the gender gap in STEM and why it is important to consider it within the larger context of changing labor relations in the new economy that has brought forth increasing labor segmentation in high-skills occupations. I then introduce the data and methods used in the study followed by a presentation of the main findings. In the discussion and conclusions I argue that a focus on measures of total compensation is necessary to create a more complete picture of the status of women in STEM in the new economy. 
Running Head: UNDERESTIMATING THE GENDER GAP?

\section{Literature Review}

\subsection{STEM employment and labor segmentation in the new economy}

Labor market segmentation (LMS) theory was advanced in the early 1970s as a challenge to human capital theory and neoclassical economic theory, the leading frameworks for studying labor markets at the time. LMS researchers were concerned with the persistence of poverty and underemployment in the U.S. in spite of general economic prosperity in the post-World War II period (Gray \& Chapman, 2004, p. 118). This interest led to the development of a framework that would help examine "the historical process whereby political economic forces encourage the division of the labor market into separate submarkets, or segments, distinguished by different labor market characteristics and behavioral rules" (Reich, Gordon \& Edwards, 1973, p. 359).

LMS researchers questioned the neoclassical assumption that wages, like prices, are flexible, and that labor markets tend to equilibrate ("clear") supply and demand of existing jobs through wage fluctuations. LMS researchers countered that wages do not always adjust to clear the market, and that they may be determined by more than simply supply and demand. For example, in sectors where there is a high cost (i.e. search, recruitment, and training costs) associated with replacing highly skilled or specialized workers, employers may offer above-market wages, as well as other incentives (e.g. benefits) to increase worker efficiency and loyalty. In turn, firms or industries with higher wages are likely to attract more able job-seekers. In cases where there are more applicants for a highly desirable position, many qualified workers may not get hired, a situation which would result in 
Running Head: UNDERESTIMATING THE GENDER GAP?

"queuing" for jobs in the form of unemployment, sub-employment, or job queues among employed workers (Dickens \& Lang, 1993; Thurow, 1972). ${ }^{1}$

Implicit in this efficiency wage hypothesis is the idea that high wages are usually correlated to other "good job" characteristics, such as full-time employment or access to employer-provided benefits (Hudson, 2007; Tilly, 1996). It is important to stress that in an LMS framework, isolated characteristics like wages or full-time employment are not sufficient to classify markets as secondary or primary. Rather, it is the cumulative set of job attributes, the "bundling" of job characteristics that determines a qualitative difference from one segment to another. At the heart of primary-type jobs is the idea of a "decent work agenda" which includes access to retirement and health insurance benefits, employment stability, and the right to training (Boyer, 2006; Rodgers, 2007). However, these types of measures are rare in the STEM workforce literature, as mentioned in section 2.2.

Another challenge is that, in the new economy, the employment landscape is far more fluid and variegated than in the 1960s and 1970s, when labor segmentation was first explored. The "new economy" generally refers to the shift from an industrial/manufacturing-based wealth producing economy into an export-oriented, technology-driven mode of production that relies primarily on a highly-qualified and flexible workforce. This shift marked a fundamental departure from industrial era notions of business organization and work arrangements, and most notably featured the widespread adoption of policies that facilitated corporate restructuring and the broader use of contingent

\footnotetext{
${ }^{1}$ Thurow (1975) adds that an applicant to a job cannot increase the odds of being hired by lowering his or her asking wage; this is because wage levels are determined by institutional and market forces, such as those posed by the wage-efficiency model. In situations where there is an excess of applicants for a particular job, there is a queue of candidates at the firm's door. In these circumstances, "[a]pplicants are sorted according to what the firm perceives as hiring and on-the-job training costs associated with each individual, with the least costly put at the front of the line" (Lee, 1993, p. 74).
} 
Running Head: UNDERESTIMATING THE GENDER GAP?

and nonstandard work arrangements, even amongst high-skills occupations traditionally associated with primary market employment such as technicians, professionals, and managers (Katz \& Krueger, 2016; Barker \& Christensen, 1998; Barley \& Kunda, 2006; Kunda, Barley, \& Evans, 2002; Benner, 2002; Rubery, 2004; Casey \& Alach, 2004). Such policies favored the deliberate stimulation of turnover to reduce seniority payments and worker organization, commission sales, and household production by means of computers and telecommunications (Tilly \& Tilly, 1994, p. 307). These policies also contributed to the decline of worker protections associated with union membership (Mayer, 2004), which decreased from 33\% in 1955 to $11.9 \%$ in 2010 (Hudson, 2007; Bureau of Labor Statistics, 2011).

These changes to labor relations pose an important challenge to the postulation of labor segmentation research that views factors such as job instability and contingent work as the province of low-skill jobs. There is a degree of ambiguity over the extent to which the marginalizing effects of non-standard employment (e.g. low wages, few to no benefits, no career ladders) apply to professional and managerial occupations (Kunda et al., 2002). Likewise, despite evidence that women are far likelier than men to participate in nonstandard work (Rubery, Smith, \& Fagan, 1999; Charles \& Gruzky, 2005), there is debate concerning the extent to which marginalization and unequal treatment at work disparately impact women. Scholars like Rubery et al. (1999) express concern that "[P]olarisation may emerge around those women in fulltime and those in part-time work, with the latter trapped in less skilled and "dead-end" jobs" (Rubery et al., 1999, p. 306) with limited work hours and training opportunities. For example, in the United Kingdom, an analysis of the 1998 Workplace Employee Relations Survey by Hoque and Kirkpatrick (2003) found evidence 
Running Head: UNDERESTIMATING THE GENDER GAP?

that managers and professionals on nonstandard contracts reported experiencing marginalization in terms of training opportunities and consultation at work; these outcomes were more prominent in the case of women. In contrast, Casey and Alach (2004) and Casey (2002) stress that the expectation that nonstandard forms of work are involuntarily undertaken or inherently disadvantageous to workers, especially to women, requires tempering. Their interpretive analysis of a qualitative study of women temporary workers in New Zealand found that some women in contemporary conditions of work "may be seeking not so much to advance spheres of freedom within work, but freedom from work, as rationalized, marketized labour” (p. 475).

\subsection{The gender gap in STEM}

Gender inequality in STEM takes various and complex shapes, ranging from recruitment and retention of women across educational levels (Wang, 2013; Riegle-Crumb, King, Grodsky, \& Muller, 2012; Melguizo \& Wolniak, 2012; Griffith, 2010; Whalen \& Shelley, 2010) to barriers to job entry, retention, and advancement, especially in the most lucrative fields and occupations (Fouad and Singh, 2011; Holleran, Whitehead, Schmader, \& Mehl, 2010; Beede et al., 2011; Broyles, 2009), to pay and compensation (Renzulli, Reynolds, Kelly, \& Grant, 2013; Rollor, 2014; Xu, 2015). In terms of the latter, there is evidence that the pay gap for the STEM professions has increased in recent years: pay for women was 78.7 percent of men's in 2003, a decrease from 81 percent in 1995 (Broyles, 2009).

The gender pay gap is not only an important factor contributing to the slow improvement in diversifying the STEM workforce; it is also a telling symptom of the lower status of women in society at large. Employment in STEM fields is widely considered to be 
Running Head: UNDERESTIMATING THE GENDER GAP?

amongst the most desirable due to its higher wages and relative stability compared to other occupations. Indeed, the gap between annual mean wages between STEM and non-STEM occupations increased in recent years. In May 2016 STEM occupations had an annual mean wage of $\$ 89,400$, compared with $\$ 46,950$ for non-STEM occupations (Bureau of Labor Statistics, 2016). Likewise, unemployment among science and engineering occupations has been low when compared to the overall U.S. workforce (National Science Board, 2010, 2012) and is lowest for individuals with advanced degrees (Auriol, 2010; Mullin, 2011). That the pay gap persists among the most prestigious professions and occupations speaks to the devaluation of women's labor in society (Renzulli et al., 2013; Prokos \& Padavic, 2005; Xie \& Shauman 2003; Bellas, 1994; Barbezat, 1987; Monroe, \& Chiu, 2010; Cherry, Durden, \& Gaynor, 2011).

\subsection{Underestimating the gender gap}

An important consideration in estimating the size of the gender gap in STEM occupations is the fact that most studies rely exclusively on measures of earned wages, despite robust evidence that income inequality is exacerbated by the uneven distribution of additional forms of compensation, such as employer-provided healthcare insurance and pensions (Kristal et al., 2011; Piketty \& Saez, 2003). This more comprehensive form of compensation inequality has a disproportionate negative impact on women in the general workforce (Ghillarducci \& Lee, 2005). Yet the extent to which the distribution of employment benefits and other measures of total compensation contribute to the pay gap in STEM has not been sufficiently studied. An important barrier in this regard comes from the type of data that are typically collected by dedicated science and technology education and workforce databases, such as the Scientists and Engineers Statistical Data System 
Running Head: UNDERESTIMATING THE GENDER GAP?

(SESTAT) and the Survey of Doctorate Recipients (SDR), both maintained by the National Science Foundation. For example, the SDR survey includes items on whether a respondent has access to employer-provided health insurance, but the data is only collected for respondents employed as postdocs at the time of the survey.

Implicit in the SDR data collection strategy is an assumption about the nature of STEM employment. As mentioned above, on average STEM jobs have higher wages and greater security than their non-STEM counterparts; as such, the primary labor market status of STEM jobs is largely assumed in both research and policy. However, evidence of growing labor segmentation in science and technology has been documented in an employment sector of crucial importance to STEM: academia. The "casualization" of the academic labor market has alerted researchers and policymakers to the precarious labor conditions faced by some of the most highly-trained STEM workers in the U.S., and efforts have been underway to better understand the dynamics of employment paths for postdocs in particular; the inclusion of survey items related to quality of employment (e.g. access to health insurance) in the SDR is one such measure. By not collecting broader measures of compensation, dedicated STEM databases like the SDR may inadvertently perpetuate the notion that labor segmentation is a phenomenon endemic to academic employment. Yet the restructuring of academic employment into in non-tenure-track adjunct and postdoc positions must be understood within a larger context of changing labor relations in the new economy that has brought forth increasing labor segmentation in high-skills occupations.

With these factors in mind, in this study I explored segmentation patterns in the STEM workforce using measures of total compensation that included wages, employerprovided benefits (health and retirement) unionization, second job tenure, full-time v. part- 
Running Head: UNDERESTIMATING THE GENDER GAP?

time employment. The aim of the study was twofold: to create a fuller picture of the employment landscape for STEM workers in the new economy, and through it illuminate aspects of the gender pay gap in STEM not captured by research with a primary focus on wage differentials.

\section{Methods}

\subsection{STEM definition, data, and methods of analysis}

After the National Science Board, I used a comprehensive definition of the STEM workforce that includes "all individuals educated in S\&E fields and using their skills in their jobs, not just those officially classified as a 'scientist' or 'engineer'" (Crosby \& Pomeroy, 2004, p. 25). Per this definition, individuals trained in the health and medical professions (such as physicians, surgeons, and dentists, among others) are included in the STEM workforce, as are technicians and technologists in a variety of fields. The rationale for using this definition is twofold. First, the interdisciplinary nature of scientific and technical training makes the analytical segregation of medical and STEM fields untenable (Miller \& Solberg, 2012; Kimmel, Miller \& Eccles, 2012). Second, the exclusion of technical labor and health-related occupations in much of the research on the STEM workforce has important implications for our understanding of the gender gap in these fields. More conservative definitions of the STEM workforce - such as that used by the National Science Foundation and much of the research based on their databases-include holders of a bachelor's degree or above in computer and mathematical science, engineers, life sciences, physical sciences, or social sciences.

The exclusion of associate's degrees from this widely-used definition obscures the growing importance of these degrees as access points to technical and health-related 
Running Head: UNDERESTIMATING THE GENDER GAP?

occupations for women. In 2011, women earned 62\% of all associate's degrees, including $43 \%$ of STEM associate's degrees and $85 \%$ of all health professions and related ass ociate's degrees (NSB, 2014; NCES, 2012). Significantly, the community college also offers an important pathway into science and engineering degrees for women (Fealing, Lai, \& Myers, 2015; National Academy of Engineering \& National Research Council, 2005). Women who received a bachelor's and master's degree in STEM are more likely to have attended a community college than their male counterparts (NSB, 2012). The elision of technical and health-related occupations in STEM workforce research not only perpetuates an outdated view of how scientific and technological labor are conducted at the empirical level; it also severely limits our understanding of the mechanisms through which women may be allocated to distinct segments of highly-skilled labor markets. The more comprehensive definition proposed by the National Science Board thus represents an important step in challenging the devaluation of feminized labor in highly-skilled occupations.

\subsection{Data and sampling procedure}

For this study, I used a cross-sectional sample drawn from the 2008-2010 Longitudinal Survey of Income and Program Participation (waves 1, 2, 3 \& 6). The sampling procedure included individuals who were employed at the time that the first wave of the longitudinal survey took place and who remained both in the SIPP universe and employed in the subsequent waves $(2,3$, and 6) during which the employment variables of interest were collected. I then identified respondents over 25 years old who held STEM postsecondary degrees (at the certificate level and above) and who indicated being employed in STEM professional, health-related, and technical occupations in 2008. 
Running Head: UNDERESTIMATING THE GENDER GAP?

The final sample included 3,493 observations, subdivided into three broad occupational categories: a) Individuals in STEM professional occupations; b) Individuals in STEM technical occupations; and c) Individuals in health occupations, as shown in Table 1:

[Insert Table 1 about here.]

\subsection{Data analysis}

Data analysis consisted in a two-step cluster analysis of the characteristics of the STEM jobs represented in the 2008 SIPP database. Previous LMS research has used methods such as discriminant analysis, factor analysis, and maximum likelihood switching models to identify specific labor market segments. Regardless of the method used, the results consistently point to a positive co-variation among secondary labor market characteristics (and, likewise, among primary characteristics); this co-varying feature has been used to identify discrete segments in the U.S. labor market. However, a contentious aspect of early LMS studies is that the researchers often determined a priori the number and characteristics of the segments in a sample. Critics of these early works observed that this approach was subjective, arbitrary, and susceptible to truncation bias or restricted range problems (Hudson, 2007, p. 291). Therefore, an important consideration in this study was to select a data analysis strategy that allowed me to achieve two main goals: 1) to capture the presence of coherent groups with shared employment characteristics in the SIPP sample; and 2) to avoid the a priori designation of said groups. Two-step cluster analysis is a technique that allows researchers to achieve both goals. 
Running Head: UNDERESTIMATING THE GENDER GAP?

Two-step cluster analysis is a non-parametric method for identifying homogeneous groups ("clusters") of objects (e.g. cases, observations) that share characteristics with other members of a given group, but are dissimilar to objects from other groups (Mooi \& Sarstedt, 2011). The similarity between clusters is determined on the basis of quantitative or

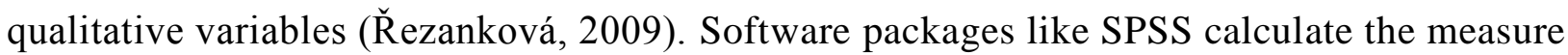
of (dis)similarity between pairs of objects. Objects with smaller distances between one another are more similar, whereas objects with larger distances are more dissimilar (Mooi \& Sarstedt, 2011). In two-step clustering the default distance of measure is log-likelihood. Because of its partitioning ability, cluster analysis is especially useful in developing exploratory or theoretically-based typologic classification of objects (Hair \& Black, 2000).

One advantage of this procedure over other methods like discriminant analysis is that the number and characteristics of the groups are to be derived from the data and are not defined a priori (Afifi, May, \& Clark, 2012). Two-step clustering automatically determines the number of clusters based on statistical measures-of-fit, such as Akaike's Information Criterion (AIC) or Bayes Information Criterion (BIC) (Mooi \& Sarstedt, 2011), and thus does not require that the researcher establish an a priori clustering solution. Because twostep cluster analysis allows for complex configurations of segmentation to emerge from the data themselves, the risk of truncation bias that has been associated with some segmentation studies is thus minimized.

Although the technique is commonly associated with fields that rely heavily on data mining, such as market research, in education cluster analysis has proved useful to explore phenomena ranging from the relationship between students' beliefs about knowledge (i.e., epistemological beliefs) and their learning and performance (Buehl \& Alexander, 2005), the 
Running Head: UNDERESTIMATING THE GENDER GAP?

ontogeny of children's early failure in school (Speece \& Cooper, 1990), the nature of reading comprehension difficulties among early adolescent language minority (LM) learners and native English speakers in urban schools (Lesaux \& Kieffer, 2010), as well as in the creation of typologies of collegiate leadership programs (Owen, 2008), and of perfectionist traits in academically talented children (Parker, 1997).

\subsection{Variables}

Cluster analysis requires the selection of variables with high criterion validity regarding the phenomenon under consideration. SIPP 2008-2010 provides data on key variables that prior research has identified as highly relevant to segmentation dynamics: monthly wages, access to employer-provided health insurance and retirement benefits, unionization, and access to training by employer. To capture aspects of employment restructuring, I also included part-time and multiple employment ("second job" in either a STEM or non-STEM occupation) as clustering variables. The selected variables met the low to medium collinearity thresholds required by clustering procedures. Additionally, I ran Chi-Square tests between the categorical employment variables to test their independence. As predicted by LMS theory, there was a significant association between each pair of clustering variable (all $\mathrm{p}<.001$ ), but the levels of association were sufficiently low to ensure the variables' suitability to be included in the cluster analysis. The weak to medium-sized association between the categorical employment variables ranged from $\mathrm{V}=.09$ (for part-time and second job variables) to $\mathrm{V}=.46$ (for wages quintile and health insurance variables). ${ }^{2}$

\footnotetext{
${ }^{2}$ Because the selected variables for clustering (and indeed, most of the SIPP variables used for the study) were categorical, I used Cramer's V coefficients to determine the size of the association between each pair of variables.
} 
Running Head: UNDERESTIMATING THE GENDER GAP?

In segmentation research, isolated characteristics like wages or contingent employment are not sufficient to classify markets as secondary or primary. Rather, it is the cumulative set of job characteristics, the "bundling" of job characteristics that determines a qualitative difference from one job to another. Under the two-step cluster design, evidence of segmentation would show as an array of distinct groups of workers with similar combinations of primary- and secondary-market characteristics. In the findings section, I first present the clustering solution and discuss the segmentation pattern evident in it, as well as the characteristics of the clusters.

\subsection{Limitations}

For this study, I used the 2008-2010 survey (waves 1, 2, 3 \& 6). The initial sample included only those individuals who were employed at the time the SIPP 2008 survey took place, and who remained both in the SIPP universe and employed in the subsequent waves $(2,3$, and 6$)$ during which the variables of interest were collected. That means that the findings of the study are only generalizable for these respondents, and cannot be extended to workers who may have left the SIPP universe (e.g. became institutionalized or left the country), or who may have been employed in one SIPP wave but not in another. This is an important caveat, in that the 2008-2009 period (which comprises the SIPP waves used in this study) was marked by extraordinary turbulence in both the U.S. and global labor markets. The present study cannot account, for example, for SIPP respondents who were employed at the time of the first wave, but who lost their jobs at a later point.

An important limitation of this study is that it uses STEM workforce-wide measures. As shown in this article, this approach is useful for examining broad employment trends. One disadvantage, however, is that it precludes the examination of field- and occupation- 
Running Head: UNDERESTIMATING THE GENDER GAP?

specific segmentation dynamics that could more precisely control for specialized education, job training, geographic location, and other potential compensation determinants. Speaking from the context of STEM education, Kanny et al. (2014) have observed that "[T]he lack of subfield research "does further disservice to the topic of the gender gap by presuming that the explanations for women's underenrollment in computer science (for example) are the same as those for engineering or physics." The topical module in Wave 2 of the 2008 SIPP covers education and training information. Individuals are asked if they have completed various levels of schooling, including a $\mathrm{PhD}$, professional degree, baccalaureate degree, associate degree, vocational certificate, high school diploma, or less than four years of high school. The respondents are also asked to provide the broad field of study of their highest degree. Because SIPP is a non-STEM dedicated database, the field of study item constitutes a rather rudimentary indicator of the respondents' field of study. This is a limitation of the SIPP database in relation dedicated STEM datasets, which provide detailed information about main field as well as subfields of study.

\section{Findings}

The two-step cluster analyses revealed the presence of labor segmentation consistent with LMS theory, including most importantly the presence of "secondary" clusters marked by wages below the national average for the entire U.S. workforce, contingent status, few to no benefits, and a lack of access to training opportunities. At the same time, a number of clusters emerged with patterns that challenge the clear-cut distinction between employment segments predicted by classic LMS theory. Particularly, the analysis showed the presence of "primary contingent" workers who receive high wages as well as health and retirement 
Running Head: UNDERESTIMATING THE GENDER GAP?

benefits, but who are employed in part-time or contingent arrangements. Significantly, women were overrepresented in both the secondary and the primary contingent clusters.

\subsection{Two-step clustering solution}

The clustering solution rendered by SPSS divided the observations into 10 clusters (see Figure 1), and included a total of 3,144 observations, or $90 \%$ of the sample. A goodness-of-fit BIC score of 0.7 indicates that the resulting model fits the data satisfactorily. Because all the clustering methods available in SPSS are sensitive to case order, it is crucial to assess the solution's stability and validity to ensure that cluster profiles represent meaningful, non-random groupings of observations (Speece \& Cooper, 1990). In accordance with recommendations in the literature, I split the dataset into two randomized sets of observations, then analyzed the two subsets separately using the same parameter settings. Running the clustering procedure on the randomized subsamples resulted in the same number of clusters and model fit, indicating that the clustering solution is stable. To further test the clustering solution's stability, I ran the analysis again using Akaike's Information Criterion (AIC) as an alternate goodness-of-fit measure to the default Bayesian Information Criterion (BIC) used by SPSS. Both procedures yielded the same number and internal distribution of clusters.

The clustering solution produced by SPSS is shown as a visual array in Figure 1. Each column represents a cluster. By default, SPSS organizes clusters from left to right by size in terms of number of observations (row 3). The "Prototypical Primary 1" cluster is the largest, with a total of 977 observations, followed by "Contractor 7" (346), "Prototypical Primary 8" (325), “Upper Middle 4" (295), "Upper Middle 6" (264), "Upper Secondary 5" (250), “Unionized 9” (237), “Lower Secondary 2” (223), “Lower Middle 3” (177), and 
Running Head: UNDERESTIMATING THE GENDER GAP?

"Elite 10" (50). Each of the rows below represents a clustering variable and shows the mean or modal values for that variable in a given cluster.

[Insert Figure 1 about here.]

To facilitate interpretation of the array, in Table 2 I have rearranged the order of the clusters in a continuum of more secondary to more primary-type characteristics, and have added names to identify each of the clusters. I have also simplified the values of each cell to facilitate visual inspection. I used modal values over $60 \%$ to determine whether an employment characteristic defines a cluster (+) or not (-). Values close to $50 \%$ are represented by $+/-$.

\section{[Insert Table 2 about here.]}

\subsection{Segmentation in the STEM workforce}

The examination of the cluster solution reveals a pattern generally consistent with segmentation theory — albeit with some important qualifications. Higher wages are consistently "bundled" with other primary employment characteristics, as do lower wages and other characteristics associated with secondary markets. The clusters in the far left of Figure 2 fall well within the parameters of the secondary market. These are workers who are employed part-time, have no access to employment benefits, and who receive low monthly wages. At least two definitions of "low" monthly wages are possible here: low in relation to the rest of the STEM workforce, and low in relation to the US workforce in general. The 
Running Head: UNDERESTIMATING THE GENDER GAP?

annual mean wage for workers in the "Lower Secondary 2" cluster was $\$ 25,692$. This figure is well below the $\$ 43,460$ annual average for the entire U.S. population, to say nothing of the mean annual wage of $\$ 77,880$ calculated for all STEM occupations by the Bureau of Labor Statistics for May 2009 (Cover, Jones \& Watson, 2011). The mean annual wages for workers in the upper-secondary cluster $(\$ 35,856)$ are likewise beneath these thresholds.

By contrast, as we move towards the right side of the array, it becomes evident that as wages increase they tend to become "bundled" with other primary-type characteristics. Clusters 1 and 8 ("Prototypical Primary") fit the classic definition of primary jobs in that their members are employed full-time, receive average wages well above the national average and have access to employer-provided training, pension, and health insurance benefits. To the left of these primary-type clusters, clusters 9 and 7 are of special significance. Cluster 9 ("Unionized") is formed by of workers who, in addition to having relatively high wages and access to benefits, are also covered by a union. In turn, Cluster 7 ("Contractor") is comprised by part-time workers with high mean wages as well as access to health and pension benefits. This "Contractor" cluster runs against the assumption in some segmentation research that part-time work is exclusively associated with secondary characteristics such as lower levels of compensation, high turnover rates, and lack of benefits.

\subsection{Representation of women in the clusters}

Having established the presence of segmentation in the STEM workforce, I examined the distribution of women in the different clusters, and what it might reveal about differential compensation patterns. As mentioned in the introduction, women in STEM occupations consistently report lower wages than their male counterparts. However, most 
Running Head: UNDERESTIMATING THE GENDER GAP?

reports on the status of the STEM workforce use wages as the main or only variable to determine this difference. This strategy tends to underestimate the actual extent of compensation differences between men and women in the general population (Ghillarducci \& Lee 2005), but the extent to which the same phenomenon is present in the STEM workforce is unknown. Because the cluster analysis uses more comprehensive measure of compensation, examining the gender composition of each cluster makes it possible to capture alternative features of the gender gap.

Examination of Figure 2 reveals a clear pattern in the distribution of female workers across STEM employment clusters: women tend to be overrepresented in the clusters with more secondary characteristics, and underrepresented in the clusters with more primary characteristics. Women and men are generally equally represented in the middle clusters.

[Insert Figure 2 about here.]

For example, even though women represent $52 \%$ of the total sample, they account for 70 and 78 percent of the "Lower Secondary 2" and "Upper Secondary 5" clusters, respectively; that is, jobs characterized by part-time employment, few to no benefits, and wages below the US national average. The representation of women drops significantly as we move towards the primary end of the spectrum, with two significant exceptions: the unionized cluster, with virtual gender parity males ( $49.8 \%$ men and $50.2 \%$ women), and the contractor cluster, composed by $63 \%$ women.

The overrepresentation of women in clusters defined by part-time employment is noteworthy. The characteristics of part-time employment in the "Lower Secondary 2" and 
Running Head: UNDERESTIMATING THE GENDER GAP?

"Upper Secondary 5" clusters seem of a very different nature than those of the "Contractor 7" cluster, which is associated with significantly higher wages as well as access to health and pension benefits. This phenomenon brings to mind the observation that highly remunerated part-time work is likely to be appealing for women, and more specifically mothers with young children (e.g., Feldman, 2006). The SIPP data allowed me to test whether there was a significant association between gender and the number of workers in the "Contractor 7" cluster who had children under 18 . However, the results for the test supported the null hypothesis of independence $\left(\chi^{2}(1)=.207 \mathrm{p}>.05\right)$. In other words, the contractual cluster is not comprised of a high proportion of women with children under 18; indeed, less than half $(43.6 \%)$ of the women in this cluster had children under 18 . The outlook in the secondary clusters was different. For the "Lower Secondary Cluster 2," the chi-square analysis indicated an association between sex and having children under 18 years old $\left(\chi^{2}(1)=10.72 \mathrm{p}>.01\right)$. Of all women in the cluster, $51.6 \%$ had children under 18 years old, compared to only $27.9 \%$ of men in the cluster. Women comprised $80.8 \%$ of those with children under 18 years old.

\subsection{Degree Attainment, work experience, and age in secondary clusters}

The presence of the "Lower Secondary 2" and "Upper Secondary 5" clusters problematizes the notion that secondary employment is predominantly low-skilled. The sample employed in this study is comprised of highly-skilled individuals holding a postsecondary certificate or above. The cluster composition by level of degree attainment can be seen on Figure 3:

[Insert Figure 3 about here.] 
Running Head: UNDERESTIMATING THE GENDER GAP?

Some of the trends in these figures are consistent with the human capital theory assumption that higher educational levels correspond with improved outcomes in the labor market. In the "Prototypical Primary" Clusters 1 and 8, we see about $75 \%$ of workers with a baccalaureate degree or above; likewise, the proportion of workers with an advanced degree is $64 \%$ in the "Elite 10 " cluster. In contrast, the proportion of workers with a subbaccalaureate degree was significantly higher in all other clusters, and highest in the "Lower Secondary 2" cluster (42\%) and the "Lower Middle 3" cluster (43\%).

Nonetheless, Figure 3 also reveals a seeming contradiction of the human capital assumption that higher levels of degree attainment correspond to faring better in the labor market: the clusters with the lowest wages and benefits had a startlingly high proportion of workers with a bachelor's degree or above $(58 \%$ in the "Lower Secondary 2 " and $63 \%$ of the “Upper Secondary 5" cluster, respectively). Because of the seemingly anomalous presence of highly-skilled workers in secondary-type employment, further exploration of the secondary clusters was of special significance. This phenomenon invited two mutually exclusive explanations congruent with human capital theory and LMS theory, respectively. First, if the secondary clusters were comprised predominantly by young, entry-level workers, this would be consistent with the expectations of human capital theory. If, by contrast, the cluster included workers who varied greatly in terms of age or experience, then there is a possibility that the secondary clusters include workers who may have been "crowded out" of jobs with more primary characteristics.

Analysis of the age and the work experience variables in sample contradicts the expectation that the workers in the secondary clusters were younger and/or predominantly 
Running Head: UNDERESTIMATING THE GENDER GAP?

new entrants to the labor market. Figure 4 shows the distribution of workers in the "Lower Secondary $2 "$ cluster by 5-years work experience brackets. If we consider entry-level workers as those who reported $<1$ up to 5 years of experience in their current occupation, we see that slightly over a third $(36 \%)$ of the workers in the "Lower Secondary 2 " cluster were relatively new to the occupation. However, the rest of the workers had considerable experience in their reported occupation: 19\% had 5-10 years of experience, 9\% had 10-15 years of experience, $13 \%$ had 20-25 years of experience and $23 \%$ reported 20 years of experience or more in their current occupation. In short, the cluster is predominantly composed of individuals with significant work experience. The "Upper Secondary 5" cluster follows a similar pattern, although with a higher proportion of workers in higher levels of work experience.

[Insert Figure 4 about here.]

One possibility is that at least some of those at the higher end of the years of experience measure have moved into part-time employment as retirement strategies. However, inspection of the age variable (Figure 5) shows that only a small proportion of workers in these clusters fell within the age categories closest to retirement (55 years or older); about $26 \%$ of the "Lower Secondary 2" cluster, and $21 \%$ of the "Upper Secondary 5" cluster. The mean (42) and median (39) age for the "Lower Secondary 2" cluster also suggest that this cluster consists primarily of workers in their prime productive years, and who as a group had considerable work experience in their respective occupations at the time of the survey. 
Running Head: UNDERESTIMATING THE GENDER GAP?

[Insert Figure 5 about here.]

\section{Discussion}

Although various interpretations of labor segmentation are possible, the existence of the phenomenon in the US labor market is well-established. The interesting question, then, is "not whether the labor market is segmented, but along what lines" (Leontaridi, 1998. p. 78). The original drive behind early segmentation work came from empirical observation of the persistent labor marginalization of women, minority, and immigrants, despite general economic prosperity in the post-World War II period and net of observable human capital characteristics (Gray \& Chapman, 2004). Since first being introduced in the 1960s and 1970s, many of the conceptual underpinnings of LMS theory—such as the notion of "primary" and "secondary" labor markets—have become an integral part of the lexicon of stratification and social mobility research. Nonetheless, the theoretical work on labor relations - including much of LMS theory-have failed to keep up with the great changes taking place in employment relations worldwide, including corporate restructuring and the radical transformation of scientific and technical knowledge production and application. "With fitting irony, standard labor markets seem to be decaying just as we begin to formulate coherent theories about them" (Tilly \& Tilly, 1994, p. 307).

A significant consequence of these changes is that the distinction between "good" and "bad" job characteristics is far more fluid than in the 1960s and 1970s. The concern for disadvantaged workers that characterized much of the early segmentation literature "might have focused too narrowly on distinctions between primary and secondary sectors and overlooked important distinctions within the primary sector" (Gray \& Chapman, 2004, p. 121). Indeed, as mentioned in section 2, many of the features associated with primary 
Running Head: UNDERESTIMATING THE GENDER GAP?

markets have been altered by corporate restructuring. While STEM work may be more resilient to these restructuring trends than other employment sectors, the findings of the present study suggest that the former is far from immune to secondary characteristics. The present exploratory cluster analysis suggests three interrelated insights into segmentation patterns in the US STEM labor market: 1) there is a degree of stratification among highlyskilled STEM occupations which encompasses not only variation in wages but is magnified by uneven access to benefits and full-time work arrangements; 2) this segmentation appears to cut across levels of degree attainment, age, and occupational experience; and 3) the analysis shows a disproportionate representation of women in secondary-type employment, as well as in both primary- and secondary-type contingent employment.

Contemporary segmentation scholars like Hudson (2007) have argued that, as discrimination along gender, racial and ethnic lines became socially and legally discouraged, new ways of meeting the demands of both public and private employers for low-wage, low cost workers evolved over the past few decades. Nonstandard labor arrangements emerged as an important component of this shift. At the same time, in an economy driven by rapid technological innovation, nonstandard labor has gained momentum as a mechanism to maximize employer flexibility.

The findings of this study both support and complicate the evidence from prior research on the gender gap in STEM fields by illustrating the cumulative impact that measures of total compensation can have in assessing the true extent of compensation disparities between men and women, and by providing evidence that the STEM labor market is far more variegated than suggested in mainstream STEM policy discourse. The emergence of the secondary and contractor clusters points to two co-existing patterns of 
Running Head: UNDERESTIMATING THE GENDER GAP?

highly-skilled nonstandard employment arrangements, each more closely aligned with secondary or primary characteristics, respectively. Kunda et al. (2002) have warned of "confounding the effects of contracting with the correlates of low-skill occupations" when studying highly-skilled occupations (Kunda et al., 2002, p. 237). This finding points to the need for STEM workforce research designed to be sensitive to the existence and characteristics of these very different types of nonstandard employment, and the function that each may play in the knowledge economy. The original conceptualization of part-time employment as a correlate of low-skilled labor is rooted in the former's function in the industrial economy to help employers "gain advantages of lower compensation and greater scheduling flexibility" (Tilly, 1991, p. 331). This function is still largely served in the new economy, as attested by rapid expansion of temporary labor in the service sector (Nicholson, 2015). At the same time, new "retention" models of part-time employment have become increasingly common in the new economy, designed to retain or attract highly-skilled workers seeking opportunities for increased flexibility and work-life balance (Tilly, 1991; Albert \& Bradley, 1997).

The presence of a secondary, contingent segment among highly-skilled STEM workers signals yet another shift in labor relations, where-for some occupational fields or subfields-a sufficient supply of highly-skilled workers means that employers do not need to adhere to a retention model. In contrast, in highly specialized or competitive occupational subfields, retention models are required to guarantee continued access to talent that may otherwise leave for better opportunities. Investigating how these different forms of contingent employment are constituted and how they operate in relation to one another may help illuminate the role that they play in sustaining inequitable structures. 
Running Head: UNDERESTIMATING THE GENDER GAP?

In this regard, the gender composition of the clusters is suggestive. The women in this sample were clearly overrepresented in clusters defined by part-time employment, but especially so in those with low-wages and no benefits. This finding lends credence to prior research documenting the devaluation of female labor and the concomitant feminization of occupations and fields of knowledge. The findings of this study suggest that, in addition to being out-earned by their male peers, women in STEM are disproportionately employed in secondary jobs. Moreover, judging by the mismatch between their cluster allocation and their credentials plus work experience, the presence of labor queues is a strong possibility. In situations where there are more qualified applicants than positions available, employers rank prospective workers based on their potential productivity and labor costs. The surplus of qualified workers who do not get hired results in queuing for these jobs in the form of unemployment or sub-employment. Once employed in a secondary job, it may be difficult to access career ladders (either vertical or lateral), which might further restrict mobility across clusters (Dickens \& Lang, 1992). Reskin and Roos (1990) contend that this process is gendered, and men are typically ranked higher than women and are given priorities in hiring, to the extent that even within the same occupation men tend to occupy subspecialties with higher compensation levels (Tao, 2016). While the exploratory nature of the present study cannot offer conclusive evidence of queuing, the gendered pattern in the secondary clusters is consistent with research indicating that women and minorities in organizations often cannot find clear, tangible paths for advancement, which can result in frustration and ultimately departure from the organization (Hunt, 2016; Glass, Sassler, Levitte, \& Michelmore, 2013; Buse, Bilimoria, \& Perelli, 2013; Cox \& Nkomo, 1991; Fouad \& Singh, 2011). 
Running Head: UNDERESTIMATING THE GENDER GAP?

Because the STEM workforce includes a wide range of occupational categories, it is critical to examine the factors that may contribute to differences in types of employment arrangements, especially concerning nonstandard employment. For example, the examination of the "parent" variable showed a marked difference in patterns between the "Lower Secondary 2" and "Contractor 7" clusters suggest an intriguing interaction between sex, parenthood status, and the type of part-time work available to these workers. However, important caveats must be noted. It is possible that the measure for "children under 18 " is not sufficiently fine-grained to capture a statistically significant relationship with gender in the "Lower Secondary 2" Cluster. It is possible that the needs and employment priorities of women with infants and very young children may be very different than those with teenaged children, yet the SIPP measure conflates them both. Further research should focus on that difference, as well as the possibility that the females in more primary-type contractual work arrangements may be more likely to be older and phasing into retirement (examination of the age distribution for the "Contractor 7" cluster was inconclusive). More broadly, conditions such as the presence of a co-parent whose job provides health insurance coverage, length of stay in the part-time arrangement, availability of childcare options, field of study, and career stage may all play a role in a) the type (primary or secondary) of contingent employment effectively available to women in certain STEM occupations, and b) the degree of choice that women in STEM occupations have in securing a specific type of employment arrangement. 
Running Head: UNDERESTIMATING THE GENDER GAP?

\section{Conclusions}

Reports on STEM employment usually emphasize (correctly) that, on average, STEM workers command higher wages than their non-STEM counterparts (e.g. Langdon et al., 2011; NSB, 2010, 2012). However, by focusing on average wages alone, this kind of statement can reify a monolithic view of the STEM labor market that in which all STEM employment is created equal. Previous research has pointed to the considerable differences between earnings in the highest-paying and lowest paying STEM occupations (Cover et al., 2011). Yet because these estimates are made using mean wages are the main — and often only-measure of interest, they may fail to capture important differences in quality of employment across STEM occupations. This omission represents a significant challenge for the creation of accurate estimates of the overall health of the STEM labor market. Likewise, it may lead to research that underestimates the extent of the gender gap in STEM in this importance sector of the U.S. economy.

This observation is not intended to discount the value of studies using earned wages as the main indicator of labor market returns. On the contrary, these studies constitute an important window into the disadvantage faced by women in this important sector of the economy (e.g., Roksa \& Levey, 2010; Renzulli et al., 2013; Rollor, 2014; Xu, 2015). However, the findings of the present study suggest that by not using more comprehensive measures of compensation, researchers may be missing important dimensions of the gender gap in STEM employment not captured by wages alone. Determining the circumstances under which this is the case-for example by examining in greater detail aspects such as subfield of study and occupation-would go a long way in enhancing our understanding of gendered structures in STEM. 
Running Head: UNDERESTIMATING THE GENDER GAP?

Finally, it behooves researchers to consider the impact of labor restructuring on highly-skilled STEM workers in general, and women in particular. An intriguing line of inquiry opened by this study concerns the diversion of STEM graduates into non-STEM occupations. In an uncertain labor market, in which employers increasingly turn to contingent work to introduce more flexibility to deal with see-sawing demand, individuals may be unwilling to take these positions or remain in them indefinitely (Man powerGroup, 2012). In such situations, career changes into non-STEM occupations may be a less costly alternative to emigration for many STEM graduates. Such changes, however, are costly for society since education is largely financed by public funds (Mishagina, 2012). Moreover, the gendered aspects of diversion need further examination. In the US, for example, only $26 \%$ of women with STEM college degrees work in STEM occupations (Man powerGroup, 2012). It is important to explore the role that the presence of employment queues and nonstandard arrangements may have on women's decisions to depart from STEM careers.

In closing, it is quite possible that women's status in STEM requires more than simply increasing their recruitment and retention in STEM educational trajectories. Without a more nuanced understanding of current employment structures, attempts to increase their representation and retention may fall short (Metcalf, 2011; Hill, Corbett \& St. Rose, 2010). Significantly, there must be a recognition that, while we must do much more to ensure equitable educational opportunities and outcomes for women in STEM, our efforts may be Sisyphean if they do not find a counterpart in labor policy. An ongoing dialogue must take place between STEM training (at all levels), employers, policymakers, and other stakeholders to truly understand not only the barriers to equity in employment relations, but the mechanisms that create and maintain gendered segmentation. 
Running Head: UNDERESTIMATING THE GENDER GAP?

\section{References}

Afifi, A., May, S., \& Clark, V. A. (2012). Practical multivariate analysis (5th ed.). Boca Raton, FL: Taylor \& Francis.

Albert, S. and Bradley, K. (1997) Managing knowledge: Experts, agencies and organizations. Cambridge: Cambridge University Press.

Auriol, L. (2010). Careers of doctorate holders: Employment and mobility patterns. OECD Science, Technology and Industry Working Papers, 2010(4).

Barker, K., \& Christensen, K. (1998). Contingent work: American employment relations in transition. Ithaca, NY: ILR Press.

Barbezat, D. A. (1987). Salary differentials by sex in the academic labor market. The Journal of Human Resources, 22(3), 422-428.

Barley, S. R., \& Kunda, G. (2006). Gurus, hired guns, and warm bodies: Itinerant experts in a knowledge economy. Princeton, NJ: Princeton University Press.

Beede, D., Julian, T., Langdon, D., McKittrick, G., Khan, B. and Doms, M. (2011). Women in STEM: A gender gap to innovation. Washington, DC: U.S. Department of Commerce, Economics and Statistics Administration.

Bellas, M. L. (1994). Comparable worth in academia: The effects on faculty salaries of the sex composition and labor-market conditions of academic disciplines. American Sociological Review, 59(6), 807-821.

Benner, C. (2002). Work in the new economy: Flexible labor markets in Silicon Valley. Malden, MA: Blackwell Publishing. 
Running Head: UNDERESTIMATING THE GENDER GAP?

Boyer, R. (2006). Employment and decent work in the era of flexicurity. Paris, France: Paris-Jourdan Sciences Economiques.

Broyles, P. (2009). The gender pay gap of STEM professions in the United States. International Journal of Sociology and Social Policy, 29(5/6), 214-226.

Buehl, M. M., \& Alexander, P. A. (2005). Motivation and performance differences in students' domain-specific epistemological belief profiles. American Educational Research Journal, 42(4), 697-726.

Buse, K., Bilimoria, D., \& Perelli, S. (2013). Why they stay: Women persisting in US engineering careers. Career Development International, 18(2), 139-154.

Bureau of Labor Statistics. (2011). News release USDL-11-0063: Union members-2010. Washington, DC: United States Department of Labor, Bureau of Labor Statistics.

Bureau of Labor Statistics. (2016). News Release USDL-17-0376: Occupational employment and wages May 2016. Washington, DC: United States Department of Labor, Bureau of Labor Statistics.

Casey, C. (2002). Work and alienation now: Work refusal, dealienation and society. Paper presented at International Sociological Association XV World Congress, Brisbane, Australia.

Casey, C., \& Alach, P. (2004). 'Just a temp?' Women, temporary employment and lifestyle. Work, Employment and Society, 18(3), 459-480.

Charles, M., \& Grusky, D. B. (2005). Occupational ghettos: The worldwide segregation of women and men. Stanford, CA: Stanford University Press. 
Running Head: UNDERESTIMATING THE GENDER GAP?

Cherry, T., Durden, G., \& Gaynor, P. (2011). Individual and Institutional Determinants of the Male Female Wage Gap among U.S. Economics Faculty. Economics Bulletin, $31(1), 245-254$.

Cover, B., Jones, J. I., \& Watson, A. L. (2011). Science, technology, engineering, and mathematics (STEM) occupations: A visual essay. Monthly Labor Review, May 2011, 3-15.

Cox, T. H., \& Nkomo, S. M. (1991). A race and gender-group analysis of the early career experience of MBAs. Work and Occupations, 18(4), 431-446.

Crosby, M. P., \& Pomeroy, J. M. (2004). What will it take for the United States to maintain global leadership in discovery and innovation? In T. K. Kelly, W. P. Butz, S. Carroll, D. M. Adamson, \& G. Bloom (Eds.), The US scientific and technical workforce: Improving data for decisionmaking (pp. 21-26). Santa Monica, CA: RAND Science and Technology.

Dickens, W. T., \& Lang, K. (1993). Labor market segmentation theory: Reconsidering the evidence. In W. A. Darity (Ed.), Labor economics: Problems in analyzing labor markets (pp. 141-180). Boston, MA: Kluwer Academic Publishers.

Fealing, K. H., Lai, Y., \& Myers, S. L. (2015). Pathways vs. pipelines to broadening participation in the STEM workforce. Journal of Women and Minorities in Science and Engineering, 21(4), 271-293.

Feldman, D. C. (2006). Toward a new taxonomy for understanding the nature and consequences of contingent employment. The Career Development International, 11(1), 28-47. 
Running Head: UNDERESTIMATING THE GENDER GAP?

Fouad, N. A. \& Singh, R. (2011). Stemming the tide: Why women leave engineering. Milwaukee, WI: University of Wisconsin - Milwaukee.

Ghilarducci, T., \& Lee, M. (2005). Female dual labour markets and employee benefits. Scottish Journal of Political Economy, 52(1), 18-37.

Glass, J. L., Sassler, S., Levitte, Y., \& Michelmore, K. M. (2013). What's so special about STEM? A comparison of women's retention in STEM and professional occupations. Social Forces, 92(2), 723-756.

Gray, J., \& Chapman, R. (2004). The significance of segmentation for institutionalist theory and public policy. In D. P. Champlin \& J. T. Knoedler (Eds.), The institutionalist tradition in labor economics (pp. 117-130). Armonk, NY: M. E. Sharpe.

Grey-Bowen, J. E., \& McFarlane, D. A. (2010). Gender compensation discrimination: An exploration of gender compensation gap and the higher education connection. Journal of Business Studies Quarterly, 2(1), 65-82.

Griffith, A. L. (2010). Persistence of women and minorities in the STEM field majors: Is it the school that matters? Economics of Education Review, 29(6), 911-922.

Hair, J. F., \& Black, W. C. (2000). Cluster Analysis. In L. G. Grimm \& P. R. Yarnold (Eds.), Reading and understanding more multivariate statistics (pp. 147-205). Washington, DC: American Psychological Association.

Hill, C., Corbett, C., \& St. Rose, A. (2010). Why so few? Women in science, technology, engineering, and mathematics. Washington, DC: American Association of University Women. 
Running Head: UNDERESTIMATING THE GENDER GAP?

Holleran, S. E., Whitehead, J., Schmader, T., \& Mehl, M. R. (2010). Talking shop and shooting the breeze: A study of workplace conversation and job disengagement among STEM faculty. Social Psychological and Personality Science, 2(1), pp. 65-71.

Hoque, K., \& Kirkpatrick, I. (2003). Non-standard employment in the management and professional workforce: Training, consultation and gender implications. Work, Employment and Society, 17(4), 667-689.

Hudson, K. (2007). The new labor market segmentation: Labor market dualism in the new economy. Social Science Research, 36(1), 286-312.

Hunt, J. (2016). Why do women leave science and engineering? ILR Review, 69(1), 199-226.

Kanny, M. A., Sax, L. J., \& Riggers-Piehl, T. A. (2014). Investigating forty years of STEM research: How explanations for the gender gap have evolved over time. Journal of Women and Minorities in Science and Engineering, 20(2), 127-148.

Katz, L. F., \& Krueger, A. B. (2016). The rise and nature of alternative work arrangements in the United States, 1995-2015. NBER Working Paper No. 22667. Cambridge, MA: National Bureau of Economic Research.

Kimmel, L. G., Miller, J. D., \& Eccles, J. S. (2012). Do the paths to STEMM professions differ by gender? Peabody Journal of Education, 87(1), 92-113.

Kristal, T., Cohen, Y., \& Mundlak, G. (2011). Fringe benefits and income inequality. Research in Social Stratification and Mobility, 29(4), 351-369. 
Running Head: UNDERESTIMATING THE GENDER GAP?

Kunda, G., Barley, S. R., \& Evans, J. (2002). Why do contractors contract? The experience of highly skilled technical professionals in a contingent labor market. ILR Review, $55(2), 234-261$.

Langdon, D., McKittrick, G., Beede, D., Khan, B., \& Doms, M. (2011). STEM: Good jobs now and for the future. Washington, DC: U.S. Department of Commerce, Economics and Statistics Administration.

Lee, M. (1993). Asian-born scientists and engineers: Their immigration flow and labor market adjustment. Korea Journal of Population and Development, 22(1), 69-88.

Leontaridi, M. (1998). Segmented labour markets: theory and evidence. Journal of economic surveys, 12(1), 103-109.

Lesaux, N. K., \& Kieffer, M. J. (2010). Exploring sources of reading comprehension difficulties among language minority learners and their classmates in early adolescence. American Educational Research Journal, 47(3), 596-632.

ManpowerGroup. (2012). 2012 Talent shortage survey research results. Milwaukee, WI: ManpowerGroup.

Mayer, G. (2004). Union membership trends in the United States. Washington, DC: Congressional Research Service.

Melguizo, T., \& Wolniak, G. C. (2012). The earnings benefits of majoring in STEM fields among high achieving minority students. Research in Higher Education, 53(4), 383405. 
Running Head: UNDERESTIMATING THE GENDER GAP?

Metcalf, H. E. (2011). Formation and representation: Critical analyses of identity, supply, and demand in science, technology, engineering, and mathematics. (Doctoral dissertation). University of Arizona, Tucson, AZ

Miller, J. D., \& Solberg, V. S. (2012). The composition of the STEMM workforce: Rationale for differentiating STEMM professional and STEMM support careers. Peabody Journal of Education, 87(1), 6-15.

Mishagina, N. (2012). The state of STEM labour markets in Canada: Literature review. Quebec, Canada: Center for Interuniversity Research and Analysis on Organizations.

Monroe, K. R., \& Chiu, W. F. (2010). Gender equity in the academy: The pipeline problem. Political Science and Politics, 43(2), 303-308.

Mooi, E., \& Sarstedt, M. (2011). A concise guide to market research: The process, data, and methods using IBM SPSS statistics. Berlin, Germany: Springer-Verlag.

Mullin, C. M. (2011). A sound investment: The community college dividend. Washington, DC: American Association of Community Colleges.

National Academy of Engineering, \& National Research Council. (2005). Enhancing the community college pathway to engineering careers. Washington, DC: The National Academies Press.

National Center for Education Statistics (2012). Associate's degrees conferred by degreegranting institutions, by sex of student and discipline division: 2000-01 through 2010-11. Washington, DC: U.S. Department of Education, National Center for Education Statistics. 
Running Head: UNDERESTIMATING THE GENDER GAP?

National Science Board (2014). Science and engineering indicators 2014. Arlington, VA: National Science Foundation.

National Science Board. (2010). Science and engineering indicators 2010. Arlington, VA: National Science Foundation.

National Science Board. (2012). Science and engineering indicators 2012. Arlington, VA: National Science Foundation.

National Science Foundation. (2016). ADVANCE: Increasing the participation and advancement of women in academic science and engineering careers. Arlington, VA: National Science Foundation.

Nicholson, J. (2015). Temporary help workers in the U.S. labor market. ESA Issue Brief \#03-15. Washington, DC: U.S. Department of Commerce. https://www.commerce.gov/news/reports/2015/07/temporary-help-workers-us-labormarket.

Owen, J. E. (2008). Towards an empirical typology of collegiate leadership development programs: Examining effects on student self-efficacy and leadership for social change (Doctoral dissertation). University of Maryland, College Park, MD.

Parker, W. D. (1997). An empirical typology of perfectionism in academically talented children. American Educational Research Journal, 34(3), 545-562.

Pierce, B. (2001). Compensation inequality. The Quarterly Journal of Economics, 116(4), $1493-1525$.

Piketty, T., \& Saez, E. (2003). Income inequality in the United States, 1913-1998. The Quarterly Journal of Economics, 118(1), 1-39. 
Running Head: UNDERESTIMATING THE GENDER GAP?

Prokos, A., \& Padavic, I. (2005). An examination of competing explanations for the pay gap among scientists and engineers. Gender \& Society, 19(4), 523-543.

Reich, M., Gordon, D., \& Edwards, R. (1973) Dual labor markets: A theory of labour market segmentation. American Economic Review, 63(2), 359-365.

Reskin, B. F., \& Roos, P. A. (Eds.) (1990). Job queues, gender queues: Explaining women's inroads into male occupations. Philadelphia, PA: Temple University Press.

Renzulli, L. A., Reynolds, J., Kelly, K., \& Grant, L. (2013). Pathways to gender inequality in faculty pay: The impact of institution, academic division, and rank. Research in Social Stratification and Mobility, 34, 58-72.

Řezanková, H. (2009). Cluster analysis and categorical data. Statistika, 3, 216-232.

Riegle-Crumb, C., King, B., Grodsky, E., and Muller, C. (2012). The more things change, the more they stay the same? Prior achievement fails to explain gender inequality in entry into STEM college majors over time. American Educational Research Journal, 49(6), 1048-1073.

Rodgers, G. (2007). Labour market flexibility and decent work. New York, NY: United Nations Department of Economic and Social Affairs.

Roksa, J., \& Levey, T. (2010). What can you do with that degree? College major and occupational status of college graduates over time. Social Forces, 89, 389-416.

Rollor, C. R. (2014). Narrowing the gender pay gap by providing equal opportunities: The need for tenured female professors in higher STEM institutions in an effort to recast gender norms. UCLA Women's Law Journal 21(2), 143-184. 
Running Head: UNDERESTIMATING THE GENDER GAP?

Rubery, J. (2004) Labour markets and flexibility. In S. Ackroyd, R. Batt, P. Thompson, \& P. S. Tolbert (Eds.), The Oxford handbook of work and organization (pp. 31-51). Oxford, England: Oxford University Press.

Rubery, J., Smith, M., \& Fagan, C. (1999) Women's employment in Europe: Trends and prospects. London, England: Routledge.

Speece, D. L., \& Cooper, D. H. (1990). Ontogeny of school failure: Classification of firstgrade children. American Educational Research Journal, 27(1), 119-140.

Tao, Y. (2016). Where do they do engineering? Gender differences in employment at the position level among engineering doctorate recipients. Journal of Women and Minorities in Science and Engineering, 22(1), 69-89.

Thurow, L. C. (1972). Education and economic equality. The Public Interest, 28, 66-81.

Thurow, L. C. (1975). Generating inequality. New York, NY: McMillan Press.

Tilly, C. (1991). Reasons for the continuing growth of part-time employment. Monthly Labor Review 114(3), 10-18.

Tilly, C. (1996). Half a job: Bad and good part-time jobs in a changing labor market. Philadelphia, PA: Temple University Press.

Tilly, C., \& Tilly, C. (1994). Capitalist work and labor markets. In N. J. Smelser \& R. Swedberg (Eds.), Handbook of economic sociology (pp. 283-312). Princeton, NJ: Princeton University Press.

Wang, X. (2013). Why students choose STEM majors: Motivation, high school learning, and postsecondary context of support. American Educational Research Journal, 50(5), 1081-1121. 
Running Head: UNDERESTIMATING THE GENDER GAP?

Whalen, D. F., \& Shelley, M. C. (2010). Academic success for STEM and non-STEM majors. Journal of STEM Education, 11(1-2), 45-60.

Xie, Y., and Shauman, K. A. (2003). Women in science: Career processes and outcomes. Cambridge, MA: Harvard University Press.

Xu, Y. (2015). Focusing on women in STEM: A longitudinal examination of gender-based earning gap of college graduates. The Journal of Higher Education, 86(4), 489-523. 
Running Head: UNDERESTIMATING THE GENDER GAP?

\section{Tables}

Table 1: STEM workers in final sample, by broad STEM occupational category

\begin{tabular}{lcc}
\hline \multicolumn{1}{c}{ Broad Occupational Field } & Observations & Percent of Sample \\
\hline STEM professional occupations ${ }^{1}$ & 1,593 & $45.5 \%$ \\
STEM technical occupations & 718 & $20.3 \%$ \\
STEM health occupations & 1,182 & $34.0 \%$ \\
$\quad$ Total STEM workers & 3,493 & $100 \%$ \\
\hline
\end{tabular}

${ }^{1}$ This category mirrors the definition of STEM workforce used by the National Science Foundation, which includes computer and mathematical science, engineers (except sales engineers), life scientists, physical scientists, and social scientists (all with a bachelor's degree and above). The complete list of occupations comprised in each category is available from the author.

Table 2: Simplified Clustering Solution

\begin{tabular}{|c|c|c|c|c|c|c|c|}
\hline & $\begin{array}{c}\text { Mean } \\
\text { Monthly } \\
\text { Wages } \\
\end{array}$ & $\begin{array}{c}\text { Health } \\
\text { insurance }\end{array}$ & Pension & Training & Union & Part-time & $\begin{array}{c}\text { Second } \\
\text { job }\end{array}$ \\
\hline Lower Secondary 2 & $\$ 2,141$ & - & - & - & - & + & - \\
\hline Upper Secondary 5 & $\$ 2,988$ & - & + & - & - & + & - \\
\hline Lower Middle 3 & $\$ 3,978$ & - & - & - & - & - & - \\
\hline Middle 4 & $\$ 4,952$ & - & + & - & - & - & - \\
\hline Upper Middle 6 & $\$ 5,055$ & + & - & - & - & - & - \\
\hline Unionized 9 & $\$ 4,994$ & + & + & - & + & - & - \\
\hline Contractor 7 & $\$ 5,245$ & + & + & - & - & + & - \\
\hline $\begin{array}{l}\text { Prototypical } \\
\text { Primary } 1\end{array}$ & $\$ 6,133$ & + & + & - & - & - & - \\
\hline $\begin{array}{l}\text { Prototypical } \\
\text { Primary } 8\end{array}$ & $\$ 6,307$ & + & + & + & - & - & - \\
\hline Elite 10 & $\$ 30,224$ & + & + & - & - & - & - \\
\hline
\end{tabular}


Running Head: UNDERESTIMATING THE GENDER GAP?

\section{Figures}

Figure 1: SPSS Clustering Solution

mpus Presicton masanse

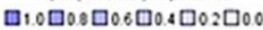

\begin{tabular}{|c|c|c|c|c|c|c|c|c|c|c|}
\hline \multirow{2}{*}{$\begin{array}{l}\text { Couster } \\
\text { Lubel }\end{array}$} & \multirow{2}{*}{$\begin{array}{c}1 \\
\text { Ptotespical Primarr }\end{array}$} & \multirow{2}{*}{$\frac{1}{\text { Contratsoe }}$} & \multirow{2}{*}{ Prototoic at Primary } & \multirow{2}{*}{4} & \multirow{2}{*}{ nosso } & 5 & , & 2 & 3 & 10 \\
\hline & & & & & & Usoer Secendary & Unionized & tower seconsary & wiss: & $E 20$ \\
\hline sise & ]$^{31.18}(8)$ & ] & $\begin{array}{l}10,38 \\
025:\end{array}$ & $\begin{array}{l}9.48 \\
(295)\end{array}$ & $8.4 \%$ & $\begin{array}{l}805 \\
12 \%\end{array}$ & $\begin{array}{l}755 \\
(237)\end{array}$ & $\begin{array}{l}718 \\
(225)\end{array}$ & $\begin{array}{l}56 \% \\
117 \%\end{array}$ & 168 \\
\hline \multirow[t]{7}{*}{ nouts } & contegrouiso & 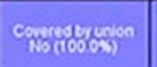 & 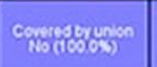 & conteditsunion & 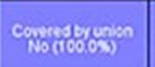 & contredsyon & 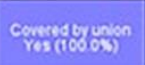 & contedgention & contedsyison & 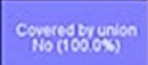 \\
\hline & 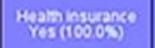 & 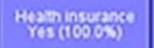 & 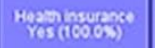 & मер. & 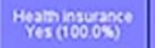 & 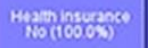 & 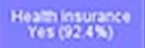 & 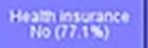 & Bingsurse & 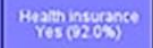 \\
\hline & 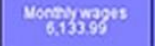 & 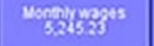 & 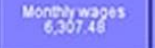 & 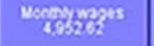 & 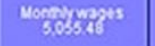 & ${ }^{\text {vortitypes }}$ & Monstopists & Nocalupass & 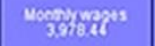 & 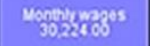 \\
\hline & $\begin{array}{l}\text { Panternyoger } \\
\text { Norionos) }\end{array}$ & 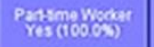 & Panternyoser & Patsmentorkar & Pantimaxyonet & Partespowoder & 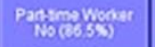 & Paramentorker & 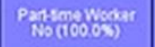 & 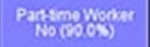 \\
\hline & 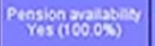 & 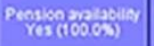 & 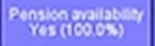 & 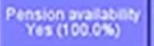 & 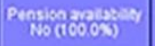 & 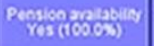 & 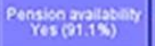 & 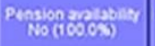 & 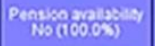 & 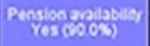 \\
\hline & Recentatanim & Rectindesing & 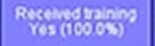 & 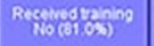 & Recentsofing & Rectivegraning & Recendation & Rucevedyanine & Recthestoing & Retelvestaning \\
\hline & $\begin{array}{l}\text { Respondent has a } \\
\text { seceond jos } \\
\text { No (1000\%) }\end{array}$ & $\begin{array}{c}\text { Respondenthas a } \\
\text { itecend (job) } \\
110(1000 \mathrm{~s})\end{array}$ & $\begin{array}{c}\text { Respondenthas a } \\
\text { second jos } \\
10(1000 \%)\end{array}$ & 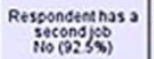 & $\begin{array}{l}\text { Respondent has a } \\
\text { secespd } \\
\text { No }(100.0 \%)\end{array}$ & 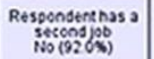 & 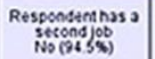 & $\begin{array}{c}\text { Respondent has a } \\
\text { socond } \\
10(96 \mathrm{~s} / 5)\end{array}$ & $\begin{array}{c}\text { Ressondent has a } \\
\text { iscond } \\
160(94 \mathrm{sis})\end{array}$ & $\begin{array}{l}\text { Responotenthas a } \\
1+6000100 \\
10(1000 \%)\end{array}$ \\
\hline
\end{tabular}

Figure 2: Cluster Composition by Sex of Workers

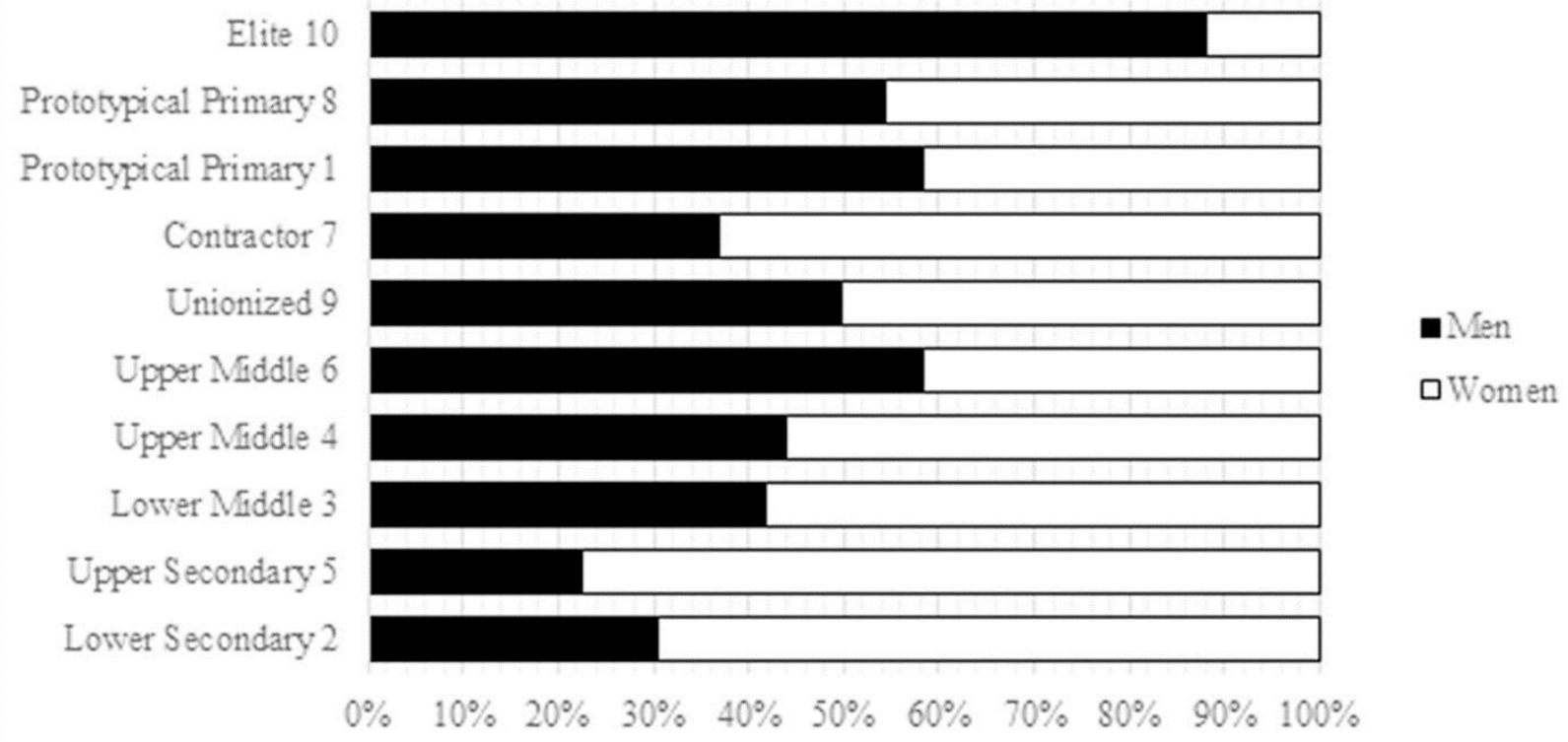


Running Head: UNDERESTIMATING THE GENDER GAP?

Figure 3: Cluster Composition by Degree Attainment

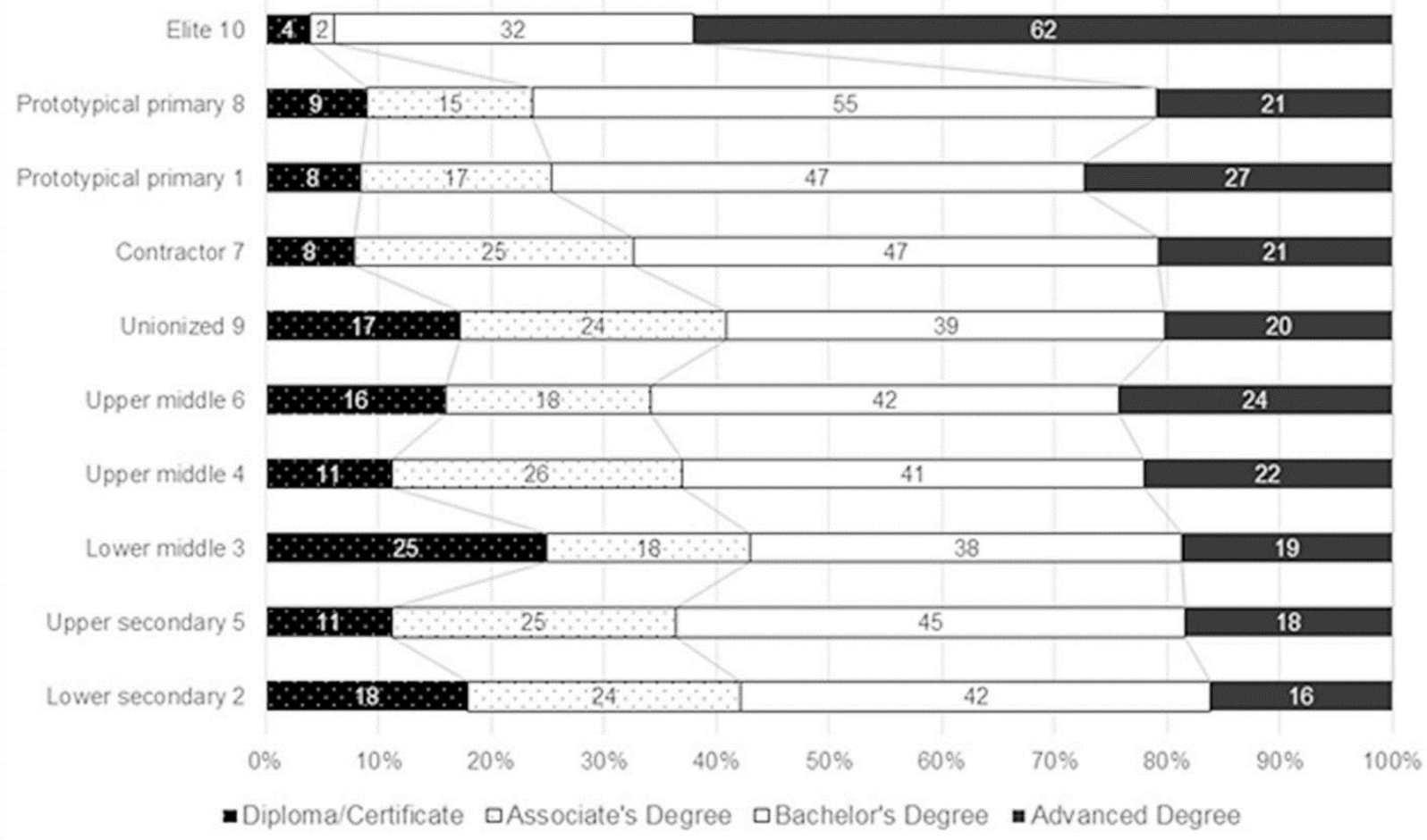


Running Head: UNDERESTIMATING THE GENDER GAP?

Figure 4: Composition of Lower and Upper Secondary Clusters, by Years in Current Occupation

Lower Secondary 2

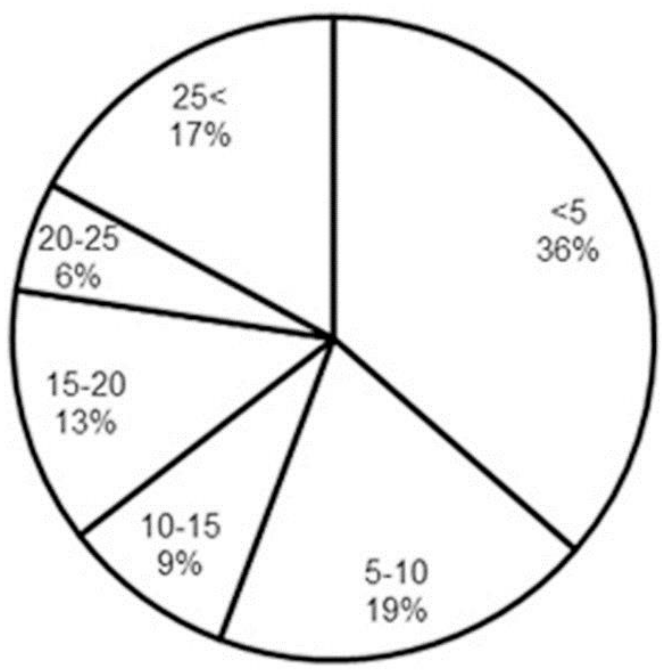

Upper Secondary 5

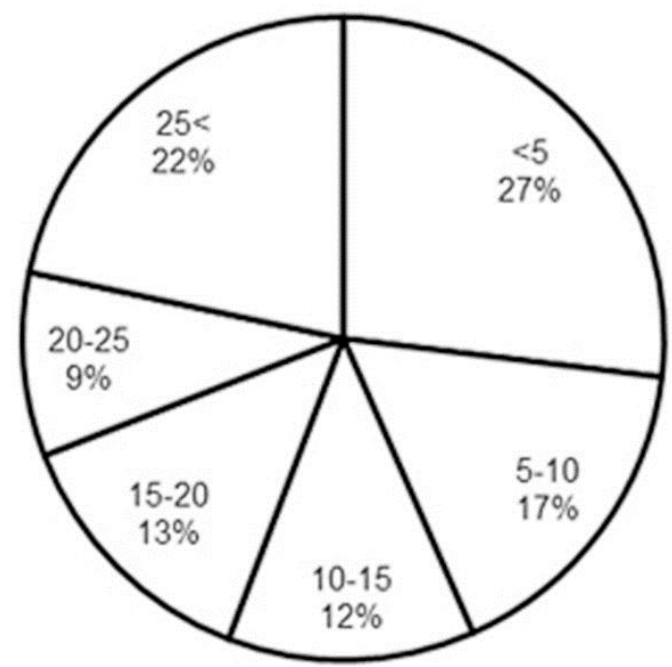

Figure 5: Composition of Lower and Upper Secondary Clusters, by Percent of Workers in Age Brackets

Lower Secondary 2

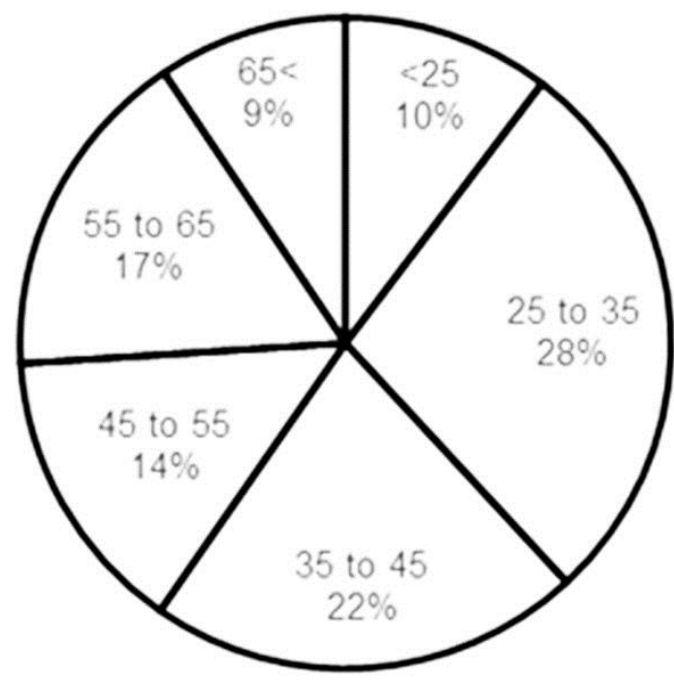

Upper Secondary 5

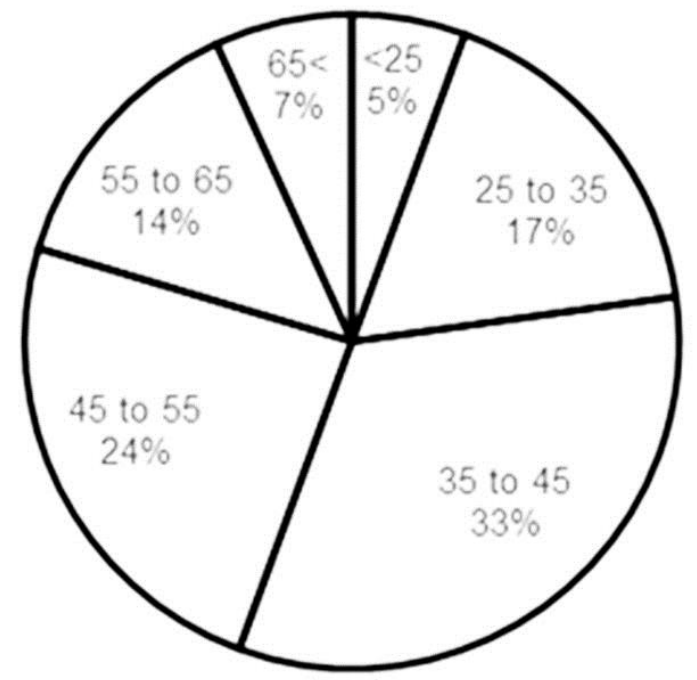

